\title{
University Students’ Employability Skills Model Based on Chinese Employer Perspective
}

\author{
Xiaobing Zhang ${ }^{1}$, Xin Zou ${ }^{2}$ \\ ${ }^{1}$ School of Economics and Management, Huaiyin Institute of Technology, Huaian, China \\ ${ }^{2}$ Department of Equipment, Huaiyin Institute of Technology, Huaian, China \\ Email: zhangxb3758@sina.com,zouxin@mail.hyit.edu.cn
}

Received August 1, 2013; revised August 31, 2013; accepted September 8, 2013

Copyright (C) 2013 Xiaobing Zhang, Xin Zou. This is an open access article distributed under the Creative Commons Attribution License, which permits unrestricted use, distribution, and reproduction in any medium, provided the original work is properly cited.

\begin{abstract}
The employability and the employability skills of the university students in China are now being the most important capacity which the employers pay the highest attention to. The aim of this research was to identify the university students' employability skills and college students' employability skills framework to reinforce the employability research and the field of human resource development (HRD) in the Chinese context. From the perspective of the employers, using the methods of interview and questionnaire, this paper studied the contents of the students' employability skills which the Chinese employers recognized and got the model of university students' employability skills. The results showed that college student's personal characteristics perceived by the service industry employers and the manufacture industry employers major focused on honesty, independence, self-confidence, adaptability, and enthusiasm. Basic knowledge which perceived by the service industry employers and the manufacture industry employers centralized political knowledge, and economic knowledge. Interpersonal relationship, teamwork, strain capacity, problem handling capacity, leadership, information technology software applications, and presentation skills were the abilities at present and in the next five years that both industry employers thought very important skills and abilities. The conclusions can be got that the employability skills perceived by Chinese employers whether in service industry or in manufacture industry include personal qualities, basic knowledge, skills and abilities. The employability skills framework perceived by employers at present in service industry and in manufacture industry is slightly different. On the contrary, it is surprising that the employability skills at present and in the next 5 years perceived by service industry employers or manufacture industry employers have a significant difference alternatively. Suggestions on managerial implications and future research directions are put forward respectively.
\end{abstract}

Keywords: Employer; University Student; Employability Skills

\section{Introduction}

In a knowledge economy, the development of the economy relies on the knowledge-driven, and the prosperity of the corporation and the nation depends on such as the upgrade of the knowledge, skills, ability of the labors and the entrepreneurial enthusiasm. Job security now has been difficult to be protected. Enterprises rely more on enhancing the employability skills [1-4] of staffs to attract, motivate and retain knowledge workers. Enterprises no longer promise a stable workplace, or give a long-term employment commitment to their staffs. Employees need to access to the value of knowledge, skills, abilities and other characteristics which their current and future employers will give high attention so that they need to maintain employment and to ensure future employment. The strategies of the reorganization of large enterprises, flatter organizations and the sustainable competitiveness allow them not only to retain the inherent high degree employability skills employees, but also to recruit such potential employees outside the enterprises. Employees who have been dismissed are no more limited to the one who is low-skilled or lack of skills. Employees' job security is now being more depending on their employment and employability skills [3,5]. Currently, there is no clear definition of the employability skills $[1,2$, 6-8]. Many studies suggest that employability skills are the capacity of employment [9-11], which can make the employees get, maintain or even get a new employment. The knowledge, skills, abilities, characteristics and behavior of the individuals are the indictors which can be quantified in the employability skills.

The annual number of university graduates in China is 
constantly rising, while the growth of social demand is slow according to previous years. The mismatch of supply and demand also leads to a stricter demand of employers. When interviewed, the employers not only recognize the importance of professional skills but also the generic skills. The generic skills [12-14] are not only the ability of initial employment, but also the potential development. In general, employers now pay more and more attention to the employability and employability skills of the staffs [15-21]. How to know and understand the employability skills which the employers value [11$14]$ is now being an important issue which the education sectors need to confront with.

\section{The Research Purpose, Object and Methods}

\subsection{Research Purpose}

The purpose of research is to get the contents of the university students' employability skills and college students' employability skills framework using the samples of the employers of service and manufacture enterprises and the in-depth interviews and questionnaires about the employers.

\subsection{Research Object and Research Methods}

In this study, the employers of the service and manufacture industries are the research object. The service industries of the survey are mainly distributed in the sector of Nanjing and Lianyungang, including dining, shopping malls, hotels, tour companies, mobile companies, telecom companies and human resources. The manufacturing sector is mainly distributed in a number of companies in Nanjing and Changzhou. On the one hand, these companies almost cover the basic characteristics of the service and manufacturing industry. On the other hand, because of the policy, economy, geography of Nanjing, Lianyungang and Changzhou are special, the employability and employability skills which the employers from the service and manufacture industries valued are representative and forward-looking.

The research methods include literature review, interviews and questionnaire survey. The main source of the study mainly comes from Chinese science and technology journal data, Superstar Digital Library, and China National Knowledge Infrastructure (CNKI).

\section{A Study of the College Students' Employability Skills Framework Based on Chinese Employer Perspective}

\subsection{Research Process}

This research process has three phases. The first stage is the preparation stage. The researchers read many of the employability literature, determine the research topic, and select research object and questionnaire. The second stage is the implementation stage. The author interviewed seven service enterprise employers and six manufacturing enterprise employers. The third stage is data collection and analysis stage. The researcher analyzes the interview and questionnaire results.

Interview outline mainly divided into two parts. The first part is personal information, including age, record of formal schooling, position, etc. The second part is questions about employability skills, including the following questions: How many general other qualities do you feel your staff have? What basic ability you think that college students usually need to have? In the said basic ability, what capacities you think in the future five years is more important?

The author interviews service enterprise employers and manufacturing enterprise employers individually. Before interview, the researcher and employers appointed interview time, place, and record agreement. Because of sensitive topic, this study did not listed detailed interview information. Then the author collected the interview information and extracted the 27 item of employability skills, 9 personal characteristics, 10 major employers valued employability skills.

Self-made university student employability skills questionnaire mainly includes two parts. The first part is samples of materials, including gender, age, records of formal schooling, position, the name, nature, the field, and the size. The second part is college student employability skills questionnaire. According to the employability skills and personal qualities from the interview, the researcher design questionnaire items and survey the importance of using ability and skill of college students and skills importance over the next five years. The questionnaire is designed by Likert five-point scales. Item ranges from "very important" to "strongly important". "1" represents not important, "2" represents little important, “3” represents important, “4” represents very important, "5" represents strongly important.

The entire investigation lasted nearly eleven months, March 13, 2011 to February 13th, 2012. With the correspondent's help, the researcher distributed the questionnaires to respondents one by one. 110 questionnaires were distributed, which were distributed to service enterprise employers 60 questionnaires, 45 were recovered, and the effective recovery rate was 58.3 percent. Which were distributed to manufacturing enterprise employers 50 questionnaire, 35 were recovered, and the effective recovery rate was 56 percent. The researchers analyze the questionnaire and summarize that perceived college student's employability skills, the importance of personal qualities and employability skills in the next five years. 


\subsection{Research Results}

The researcher use Excel software to process the data gotten from the service industry employers. The sample of the service industry employers is shown in Table 1. We got college student's personal characteristics which perceived by the service industry employers are honesty, trustworthy, ethical behavior, endure pressure, enterprising spirit, strong sense of responsibility, self-esteem, independent, self-confident, adaptability, and enthusiasm. English ability, humanities knowledge, political knowledge, and economic knowledge hold very large proportion in college student's basic knowledge which perceived by the service industry employers. Interpersonal relationship, teamwork, strain capacity, problem handling capacity, and leadership are the employers thought very important skills and abilities. Employers in service industry also pay more attention to college student's political economy knowledge, information technology application, and innovation ability. Facing the complex economic environment and the information society, employers will pay more and more attention to these three skills to cope with the changing economic environment. The comparison between the employability skills perceived by service industry employers at present and the employability skills perceived by service industry employers in the next five years clearly tell us that interpersonal relationships, teamwork, professional morality, problem solving, and strain capacity, innovative leadership, and expression ability perceived by service industry employers at present are more important than the others, such as natural science, information technology software applications and mathematics knowledge. But talked about the employability skills perceived by service industry employers in the next five years, employee interpersonal skills, team cooperation, professional ethics, and expression ability are relatively important than the other abilities.

The sample of the manufacture industry employers is shown in Table 2. We got college student's personal characteristics which perceived by the manufacture industry employers are honesty, self-esteem, independent, self-confident, enterprising spirit, passion, strong sense of responsibility, ethical behavior, adaptability, endure pressure, and trustworthy. Mathematics knowledge, application natural science knowledge, political knowledge, and economic knowledge hold very large proportion in college student's employability skills which perceived by the manufacture industry employers. The interpersonal skills, team cooperation ability, professional morality, dealing with problems, strain ability, innovation ability, leadership, lifelong learning and development direction choosing, information technology software applications, and presentation skills are the employer thought very important skills and abilities. The comparison between
Table 1. The sample of the service industry employers.

\begin{tabular}{cccc}
\hline \multirow{2}{*}{ Variable } & \multicolumn{3}{c}{ Option } \\
\cline { 2 - 4 } sex & Item & Number & Percent \\
\cline { 2 - 4 } marriage & Male & 23 & $65.7 \%$ \\
& Female & 12 & $34.3 \%$ \\
& Marriaged & 26 & $74.3 \%$ \\
age & Unmarriaged & 9 & $25.7 \%$ \\
& Less 25 & 4 & $11.4 \%$ \\
& From 26 to 35 & 8 & $22.8 \%$ \\
Feducation & From 36 to 45 & 14 & $40.0 \%$ \\
& No less 46 & 9 & $25.8 \%$ \\
& Less middle school & 3 & $8.7 \%$ \\
& Middle school to Bachelor & 8 & $22.8 \%$ \\
& Bachelor & 16 & $45.7 \%$ \\
\hline
\end{tabular}

Table 2. The sample of the manufacture industry employers.

\begin{tabular}{cccc}
\hline \multirow{2}{*}{ Variable } & \multicolumn{3}{c}{ Option } \\
\cline { 2 - 4 } sex & Item & Number & Percent \\
\cline { 2 - 4 } marriage & Male & 17 & $60.7 \%$ \\
& Female & 11 & $39.3 \%$ \\
& Marriaged & 19 & $67.9 \%$ \\
age & Unmarriaged & 9 & $22.1 \%$ \\
& Less 25 & 5 & $17.9 \%$ \\
& From 26 to 35 & 7 & $25.0 \%$ \\
Fducation & From 36 to 45 & 11 & $39.2 \%$ \\
& No less 46 & 5 & $17.9 \%$ \\
& Less middle school & 6 & $21.5 \%$ \\
& Middle school to Bachelor & 3 & $10.7 \%$ \\
& Bachelor & 8 & $28.5 \%$ \\
& Master or Doctor & 11 & $39.3 \%$ \\
\hline
\end{tabular}

the employability skills perceived by manufacture industry employers at present and the employability skills perceived by manufacture industry employers in the next five years clearly tell us that mathematics knowledge application, expressing ability, leadership ability, innovation ability and the team cooperation ability, and interpersonal skills perceived by manufacture industry employers in the next five years are more important than skills perceived by manufacture industry employers at present. But on the contrary, the information technology software application, lifelong learning and development direction choosing, handling problems and strain capac- 
ity, professional morality, and natural sciences knowledge perceived by manufacture industry employers at present are more important than skills perceived by manufacture industry employers in the next five years.

\section{Conclusions and Future Research Directions}

From the perspective of the employers, using the methods of interview and questionnaire, this paper studied the contents of the students' employability skills which the employers recognized and got the model of university students' employability skills. The conclusions are shown as that the employability skills perceived by Chinese employers whether in service industry or in manufacture industry include personal qualities, basic knowledge, skills and abilities. The employability skills framework perceived by employers at present in service industry and in manufacture industry is slightly different. On the contrary, it is surprising that the employability skills at present and in the next 5 years perceived by service industry employers or manufacture industry employers have a significant difference alternatively.

This paper contributes to the development of a Chinese employer approach to employability skills that will help in studying and implementing employability in Chinese context and other foreign contexts. Hence, notwithstanding the importance of identifying university students' employability skills from the employer perspective, the results of our investigation reinforce the employability research and the field of human resource development (HRD) in the Chinese context and the relevance of adopting competence theory and human capital approaches to employability. With this investigation, we hope to join a growing group of employability and HRD scholars pushing to make the transition from a growing into a mature field of study.

As for managerial implications, practitioners are advised to pay more attention to the whole process of curriculum set and plan in universities. Firms can formulate recruitment plans according to their development plan and communicate such recruitment plans with universities. In this way, firms can spontaneously participate in the curriculum revision of universities and provide their own suggestions on universities' curriculum set. Firms also should become students' second classroom. Without long-term practice, students can not grasp the critical skills of employability. In western countries, especially in UK and US, that attach importance to employability development, it is popular that firms are long-term practice bases for students. However, Chinese students have a relatively short time in practice with limited results. So, universities should cooperate closely with firms to provide a practice platform for students to improve their practice ability.
Further research may help explore and clarify these (and other) relevant questions. For instance, it may be interesting to deepen the research into the factors that affect the achievement of employability skills and knowledge by universities and organizations. It may be hard sometimes to attract talented employees entering the organization, so what is really important is that these employees' employability skills have been somehow transferred and have become embedded in the values and processes of organizations, especially in the socialization of organization. With this socialization and the orientation to work, it seems wise and logical to construe the relationship between the transferred employability skills and knowledge from as comprehensive an employer perspective as possible and individual performance and organizational performance by empirical study. Moreover, the field is in urgent need of more comparison research to develop and compare the existing employability skills frameworks currently founded in the Chinese context with the employability skills in the foreign context.

\section{Acknowledgements}

Financial support from Jiangsu provincial educational science project "A Study of the Composing and Forming Mechanisms of Employer-based University Students' Employability" (Project\#: D/2009/01/027), the Major Teaching Reform project of Huaiyin Institute of Technology "Innovation Study and Practice of Employabilitybased Talent Cultivating Pattern Reform" (Project\#: JG2008004), and the project of Humanities and Social Sciences of Ministry of Education of China (Grand No. 11YJA630201) are acknowledged.

\section{REFERENCES}

[1] L. Harvey, "Defining and Measuring Employability,” Quality in Higher Education, Vol. 7, No. 2, 2001, pp. 529-551. http://dx.doi.org/10.1080/13538320120059990

[2] J. Hillage and E. Pollard, "Employability: Developing a Framework for Policy Analysis,” DFEE Research Report RR85, Department for Education and Employment, London, 1998.

[3] G. X. Song and J. Y. Xie, "The Employability Education Mode: Theory Review and Practice Application,” Compare Education Research, Vol. 34, No. 5, 2008, pp. 6267.

[4] J. Brennan, J. Brenda, L. Brenda, S. Tarla and W. Alan, "The Employment of UK Graduates: Comparisons with Europe and Japan,” Higher Education Funding Council for England, Bristol, 2001.

[5] Y. Zhao and D. Y. Hao, "Talents Cultivation Logic of Higher Education in Education Popularized Era,” Modern Education Science, Vol. 12, No. 1, 2005, pp. 96-97.

[6] C. M. V. Heijde and B. I. J. M. V. Heijden, “A Competency-Based and Multidimensional Operationalization 
and Measurement of Employability," Human Resource Management, Vol. 45, No. 8, 2006, pp. 449-476. http://dx.doi.org/10.1002/hrm.20119

[7] A. Forrier and L. Sels, “The Concept Employability: A Complex Mosaic," International Journal of Human Resources Development and Management, Vol. 3, No. 2, 2003, pp. 102-124. http://dx.doi.org/10.1504/IJHRDM.2003.002414

[8] M. Fugate, A. J. Kinicki and B. E. Ashforth, "Employability a Psycho-Social Construct, Its Dimensions, and Applications," Journal of Vocational Behavior, Vol. 65, No. 3, 2004, pp. 14-38. http://dx.doi.org/10.1016/j.jvb.2003.10.005

[9] A. B. Guzman and K. O. Choi, "The Relations of Employability Skills to Career Adaptability among Technical School Students," Journal of Vocational Behavior, Vol. 82, No. 3, 2013, pp. 199-207. http://dx.doi.org/10.1016/j.jvb.2013.01.009

[10] A. Ramli, R. Nawawi and M. P. P. Chun, "Employees' Perception of Employability Skills Needed in Todays Workforce among Physiotherapy Graduates," ProcediaSocial and Behavioral Sciences, Vol. 7, No. 1, 2010, pp. 455-463.

[11] M. Y. Husain, S. B. Mokhtar, A. A. Ahmad and R. Mustapha, "Importance of Employability Skills from Employers' Perspective,” Procedia-Social and Behavioral Sciences, Vol. 7, No. 1, 2010, pp. 430-438.

[12] M. Rahmat, K. Ahmad, S. Idris and N. F. A. Zainal, "Relationship between Employability and Graduates' Skill,” Procedia-Social and Behavioral Sciences, Vol. 59, No. 17, 2012, pp. 591-597.

[13] J. Verran, "Encouraging Creativity and Employability Skills in Undergraduate Microbiologists," Trends in Microbiology, Vol. 18, No. 2, 2010, pp. 56-58. http://dx.doi.org/10.1016/j.tim.2009.12.006
[14] G. Andrews and M. Russell, "Employability Skills Development: Strategy, Evaluation and Impact," Higher Education, Skills and Work-based Learning, Vol. 2, No. 1, 2012, pp. 33-44. http://dx.doi.org/10.1108/20423891211197721

[15] N. F. Warraich and K. Ameen, "Employability Skills of LIS Graduates in Pakistan: Needs and Expectations,” Library Management, Vol. 32, No. 3, 2011, pp. 209-224. http://dx.doi.org/10.1108/01435121111112916

[16] S. Rosenberg, R. Heimler and E. Morote, "Basic Employability Skills: A Triangular Design Approach,” Education + Training, Vol. 54, No. 1, 2012, pp. 7-20.

[17] G. Baker and D. Henson, "Promoting Employability Skills Development in A Research-Intensive University," Education + Training, Vol. 52, No. 1, 2010, pp. 62-75.

[18] X. Zhu, P. Iles and J. Shutt, "Employability, Skills and Talent Management in Zhejiang Province,” Journal of Chinese Entrepreneurship, Vol. 3, No. 1, 2011, pp. 24-35. http://dx.doi.org/10.1108/17561391111106007

[19] J. Poon, “Real Estate Graduates’ Employability Skills: The Perspective of Human Resource Managers of Surveying Firms,” Property Management, Vol. 30, No. 5, 2012, pp. 416-434. http://dx.doi.org/10.1108/02637471211273392

[20] A. Panagiotakopoulos, "Employability Skills Development in Greek Higher Education Institutions (HEIs): Implications for Policy Makers," Higher Education, Skills and Work-based Learning, Vol. 2, No. 2, 2012, pp. 141150. http://dx.doi.org/10.1108/20423891211224621

[21] V. Wickramasinghe and L. Perera, “Graduates', University Lecturers' and Employers' Perceptions towards Employability Skills,” Education + Training, Vol. 52, No. 3, 2010, pp. 226-244. 